\title{
The history of sport in the international scenery: an overview
}

\author{
Wray Vamplew[1]
}

\begin{abstract}
Sport history is the sports memory of a nation, but it is a contested terrain because of conflicts over the nature and validity of evidence and theory application. It has developed academic societies, which publish journals; however, there is also a strong tradition of amateur research. Suggestions are made for a research agenda and directions in which the subject may progress.
\end{abstract}

Keywords: sport history; public history; theory.

\section{História do esporte no cenário internacional: visão geral}

\section{Resumo}

A história do esporte é a memória esportiva de uma nação, mas é um terreno contestado por conta dos conflitos envolvendo a natureza e a validade das provas e da aplicação teórica. Desenvolveu sociedades acadêmicas que publicam jornais; porém, também existe uma forte tradição de pesquisa amadora. Sugere-se o planejamento da pesquisa e das direções nas quais o sujeito possa progredir. Palavras-chave: história do esporte; história púbica; teoria.

\section{Historia del deporte en el escenario internacional: visión general}

\section{Resumen}

La historia del deporte es la memoria deportiva de una nación, pero es un terreno discutido debido a los conflictos envolviendo la naturaleza y la validez de las pruebas y de la aplicación teórica. Desarrolló sociedades académicas que publican diarios; sin embargo, también existe una fuerte tradición de investigación amateur. Se sugiere el planeamiento de la investigación y de las direcciones en las cuales el sujeto pueda progresar.

Palabras clave: historia del deporte; historia pública; teoría.

\section{L’histoire du sport dans la scène internationale: un aperçu}

\section{Résumé}

L'histoire du sport est la memoire du sport d'une nation, mais il y a controverses en raison des conflits liés à la nature et à la validation des donnés et application de la théorie. Il ya des sociétés savantes qui publient revues, mais la recherche amateur est traditionalle. Des sugestions pour une calandrier de recherche sont faites, et nous offrons orientations pour le développement dusujet.

Mots-clés: L'histoire du sport; histoire publique; théorie. 
ports history's major contribution to the study of sport is time dimension. It can be considered the sports memory of a nation: without it, there is sporting amnesia. It can set straight the sporting record but it can also explain why some things changed and why others continued unamended. History can provide the evidence to set events and incidents in their proper context and aid in explanation by giving an awareness of underlying forces. If we want to know where sport is heading, it is useful to know where it has been. It provides the benchmarks for measuring progress and change (or its lack). It can help us appreciate the difference between trend and fluctuation and realise that not everything seen as 'important' in sport needs to have a permanent influence or that everything in modern sport is new. Indeed, the sporting past has shaped the present one as all of them have some inheritance from the past be it rules, governing bodies, styles of play, competitions, or equipment.

Yet it should be emphasised that historical knowledge is always provisional. Apart from 'sportifacts', showing who won what, where and by how many, there is no absolute truth in sports history. The sports historian attempts to make sense of the past by finding evidence, interpreting and using it to come to a plausible conclusion. However, it should be recognised that sports history is a contested terrain and can be seen from different perspectives, involving diverse interrogations and interpretations of the source material.

Moreover, as Hill points out, 'history cannot be separated from historians' who have a personal relationship with the subject that can be influenced by upbringing, education, and political beliefs. ${ }^{1}$ In his seminal work, Booth has called for greater reflexivity within the discipline: 'an awareness that historians play creative roles in the production and presentation of history' and argues that historians should be more open with their value judgements and acknowledge how subjectivity affects their approach and narrative. ${ }^{2}$

\section{Development of the subject}

There are instances of early pioneers of the academic sport history who sought 'to situate their work with larger societal dialogues and paradigms.'3 Almost a century ago, Paxson wrote on the rise of American sports and the inter-war decades saw German academics documenting sources on historical sporting incidents, people, institutions, and events. However, it was not until the late 1960s that the subject really took off associated with a general historical move into 'history from below', which looked at the everyday lives of ordinary people. Almost everywhere, two schools emerged, trained via physical education and with a background in history. The former focused more on the development of particular sports, whereas the latter was concerned with how sports fitted into society. These practitioners developed sports history into a specialism to rank alongside other emerging 'new' history sub-disciplines, such as women's, labour, urban, and black histories.

If chronology and diffusion were the watchwords of human movement school, themes and context were those of historians. For them, sports history

'Jeffrey Hill, Sport in history: an introduction, Basingstoke, Palgrave Macmillan, 2011, p. 22

2Douglas Booth, The field: truth and fiction in sport history, Abingdon, Routledge, 2005, p. 211.

${ }^{3}$ Steven W. Pope (ed.), The new American sport history, Urbana, University of Illinois Press, 1997, p. 1. 
seemed to be more than ludic, and placed sports issues in a wider social, political, economic, or cultural environment. There has been tension between the two schools of thought but generally they have coexisted, often appearing on the same platforms though professing different ideologies. They are set to rise again as sport history consolidates itself in new geographical areas.

\section{Avenues of communication}

The first major sports history society was the International Committee for the History of Physical Education and Sport (ICOSH) founded in 1967 under the umbrella of the International Council of Sport Science and Physical Education. It became dominated by scholars from Eastern Europe, ensuing that political differences lead to a breakaway second organisation, the International Association for the History of Physical Education and Sport (HISPA) created in 1973. Its aim was to establish links between sports historians and all major institutions in sports science, but it should not be noted with mainstream history.

\section{Sports history seemed to be more than ludic, and placed sports issues in a wider social, poli- tical, economic, or cultural environment}

In the meantime, across the Atlantic, the North-American Society of Sport History (NASSH) was established in 1972. In Britain, the British Society for Sports History (BSSH) emerged in 1981 out of a History of Physical Education Study Group. In its inaugural conference in 1982, the current title was formally adopted. Down in the Antipodes, the Australian Society for Sports History (ASSH) was founded at the fourth biennial sporting traditions conferences.

The numerical strength of these new organisations and their reluctance to get involved in HISPA or ICOSH posed a threat to the European corporations, which, in a defensive move, assisted by the thaw in the Cold War, merged in 1989 to form the International Society for the History of Physical Education and Sport (ISHPES) with less emphasis on the scientific side of sport. Nevertheless, although this society holds conferences around the globe, it has remained Eurocentric in its administration. Another European society was founded in 1995, emerging out of the European Network of Sport Science Institutes of Higher Education. First known as CESH, it formally became the European Committee for Sports History in 2006. Although open to all sports historians, it focuses its efforts on helping young scholars in developing an European dimension in their work.

The first regularly published academic journal in the field was the Canadian Journal of History of Sport, which started in 1972 and became part of the Human Kinetics publishing empire in 1995 when it changed its name to Sport History Review. It was soon followed by the Journal of Sport History that began as the official organ of NASSH in 1973. In Australia, ASSH started publishing Sporting Traditions in 1984, which still remains the society's 
journal. Within Europe, significant sport history publications include Stadion, Internationale Zeitschrift des Sports, Revue Internationale d'Histoire du Sport, Sportzeiten, and Ludica, funded by the Benetton Foundation, which is specialised in pre- $20^{\text {th }}$ century material. More recent additions to the outlets for sport history include the CESH-sponsored European Studies in Sport History (2008), the Scandinavian-based Idrottsforum (2008) and the Brazilian Recorde (2008), the latter two are both online journals. Two others were devoted to the Olympics, the Journal of Olympic History and Olympika, which are essentially specialised in sport history outlets.

By far the most truly global in its coverage is the International Journal of the History of Sport, which started in 1984 as the commercially-produced British Journal of Sports History. However, due to internal political division and failure in getting the publisher to agree to limit subscriptions to members, it was not associated with BSSH. In 1987, still under the foundation editorship of J.A. Mangan, a new title was chosen. It recently publishes 18 issues a year including regional ones for Asia, the Americas, Australasia and the Pacific, the Middle East, Africa, and Europe. It also sponsors workshops that lead to special issues of the journal. Initially published by Frank Cass it is now under the aegis of Routledge. The BSSH's own journal was the Sport Historian that emerged in 1994 out of a newsletter that began in 1982. It was renamed Sport in History in 2003, when it was also published by Routledge.

There is also several sports journals sociology opening their pages to sport historians, among them the Journal of Sport and Social Issues, International Review of Sports Sociology, Sociology of Sport Journal, and a newcomer EAST that focuses on Asian sports.

Sport history does not appear only in academic books and articles. There is also what can be termed public sports history, generally popularising, often propagandised, and sometimes entertaining. For a discussion on the topic by leading sports historians who have been involved in public history. ${ }^{4}$ It has three major forms. First, there is what can be termed populist public history that uses media outlets, mainly television, film, and Internet. Films and television programmes are often criticised by academic historians as the historian's voice becomes mediated by producers and directors, who sacrifice historical accuracy for a story line. However, this is what attracts the viewers; and far more people watch a sports history film or programme than read history books. The Internet is often the resort of amateur historians, amassing facts about their favourite team or player and offering constant corrections to Wikipedia entries. More recently, however, a few academic sports historians have opted to put their work online with open access, read by the public is a conjectural issue.

Secondly, we have sports museums, i.e. the public face of sports history. These can be the best places to replicate performance, drama, romance, passion, and emotion of sport and they have done much to educate through entertainment. Unfortunately, too often such museums have catered to the nostalgia market and, by doing so, perpetuated myths, lacked historical objectivity and subtlety of argument, failed to contextualise artefacts, eschewed

${ }^{4}$ Douglas Booth, Mike Cronin, Murray G. Phillips, Douglas Brown, "'Our' voices in public history", Journal of Sport History, vol. 35, n. 3, p. 371-427, 2008. 
the controversial, concentrated on sport that was competitive, adult and a male-dominated activity, and had an obsession with winners and winning. A third form is the 'official' history, authorised or commissioned by a governing body or the like. Therefore, the criticism is both of omission and of commission: funders are told what they want to hear and a spin is often put on controversial issues.

\section{Evidence and theory}

History is an empirically-based, interpretive Social Science: unless there is some evidence from the past, there can be no sports history. However, the traditional evidence sources from archives and newspapers - prior to television perhaps 'the great instrument of popular communication' ${ }^{5}$ - have been supplemented by new ones. Oral history can provide a personal perception of events and what they meant to a particular group of people, giving life to historical evidence. Visual material enables us to appreciate what the past looked like. Both film and photograph confirm the very existence of the past with the first having the added dimension of movement, the body in action being a central feature of sport. Fiction could be a valuable source as it was a cultural one that shaped how people understood the world around them, but sports historians have been reluctant to use it, viewing it as unreliable and subjective. Nevertheless, novels, particularly those written within the period being studied, may cast light on the context within which sport took place and provide insights into matters on which conventional sources are opaque, in particular the role of sport in everyday life

History depends on evidence, though it is important for sports historians to interrogate their sources in order to assess their authenticity and validity. The press should be seen as a text to be interpreted rather than as a factual source to be accepted. Indeed, some aspects of reportage are on a par with inventing tradition: adding anecdotes, selecting facts, and forwarding opinion may help selling newspapers, but may tarnish them as a reliable and straightforward source material. Few sports historians have fully embraced the postmodernist view of history being virtually creative writing, but there is a greater willingness to accept that evidence can be prejudiced and privilege some information above others. What evidence is collected and saved can be functions of power in past and present societies. Hence, subordinate groups usually people who do not keep diaries, were not on committees, and were not interviewed by reporters - do not always get their voices 'heard' in historical documents. Moreover, 'evidence' can be falsified or manipulated either deliberately with the doctoring or cropping of photographs or more subconsciously when oral history interviewees confuse memory with hindsight.

Booth takes sports historians to task for a failure to engage more extensively with theory and criticises those who simply gather facts to tell a story. ${ }^{6}$ Yet, more sports historians have used theory and theoretical concepts than it was given the discipline credit for. Some of these people, particularly those from a

5Jeffrey Hill, "Anecdotal evidence: sport, the newspaper press, and history", In: Murray Phillips (ed.), Deconstructing sport history, Albany, State University of New York Press, 2006, p. 121.

${ }^{6}$ Douglas Booth, The field: truth and fiction in sport history, Abingdon, Routledge, 2005, p. 210. 
social history background, have applied theory explicitly in their work, notably that from the European philosophers Gramsci, Foucault and Bordieu joining who earlier had implicitly used Marx's ideas. Economic sports historians had always thought in an economically theoretical framework. Many of them have embraced theoretical frameworks such as modernisation, materialism, hegemony, structuration, feminism, discourse, and textualism. Thus, they adopted Howell's precept that: "to write good history [...] requires us to engage critically with the theoretical discourses that shape our historical understanding and to contemplate intellectual trends that can cross disciplinary boundaries"? Nevertheless, it is true that few sports historians explicitly discuss theoretical issues; however, many are aware of theoretical concepts and theories that they use to inform their work and help them making their explanations and arguments. Class, status, and power have featured in sports history for a long time, and as new conceptual issues emerged on the socio-political agenda, they were taken up by sports historians. For example, the linguistic turn has entered sports

$$
\begin{gathered}
\text { Few sports historians have fully embraced the } \\
\text { postmodernist view of history being virtually } \\
\text { creative writing }
\end{gathered}
$$

history and the application of cultural studies theory to historical sources is providing an avenue to explore what sport meant to players, officials, and fans. This has had two important influences on sports history. First, it helps us to understand more what people believe happened in their sporting experiences, even if they actually did not; and secondly it demonstrates how the historical text can influence on what people believe that happened in sport.

It ought to be noted that two overarching theories have been developed respectively by Guttmann and Szymanski to explain the development of sport. ${ }^{8}$ Guttmann postulated sports history's own version of 'modernisation' in which he argued that modern sport possesses seven structural characteristics. Firstly, it was secular with no religious reasons for participation. Secondly, it should demonstrate equality. Theoretically, everyone should have an opportunity to compete and its conditions should be the same for all contestants. Thirdly, it introduced the idea of specialisation: everyone who wanted could join in folk football, a sport in which there were no sharply defined roles, but the emphasis on achievement in modern sport brought in specialisation both within a sport and between sports. Fourth, rationalisation appeared, in particular the development of rules which in primitive societies were often considered 'divine instructions' - God-given rituals, not to be tampered with by mere humans; in contrast nonsecular modern sports have been invented and rules were written. Even more rationalisation came via the development of

${ }^{7}$ Colin Howell, "Assessing sport history and the cultural and linguistic turn", Journal of Sport History, vol. 34 , n. 3, 2007, p. 461.

${ }^{8}$ Allen Guttmann, From ritual to record, New York, Columbia University Press, 1978, 2004; Stefan Szymanski, "A theory of the evolution of modern sport", Journal of Sport History, vol. 35, n. 1, 2008, p. 1-32. 
coaching and sports science. His fifth feature was bureaucratisation. Almost every major modern sport has its national and international organisations, which have developed extensive bureaucracies to establish universal rules for their sport and to oversee their implementation. These were not required when there were no written rules. Sixth, it happened the quantification by which modern sports transform every athletic feat into statistics. Following on from quantification, there is his seventh point, the modern emphasis on records. Like many models, Guttmann's was an ideal-type postulation that may never have all its conditions fully satisfied. However, it has stood the test of time, if not in its entirety then as a basis on which others have built. Some critics have suggested that the model requires more input on press publicity, marketing, commercialisation, and professionalization. Others do believe that Guttmann has stuck rigidly to his original ideal type model and has refused to revise it in the light of new research findings, though they do acknow-

The linguistic turn has entered sports history
and the application of cultural studies theory
to historical sources is providing an avenue to
explore what sport meant to players, officials,
and fans

ledge he has integrated some of the critical perspectives into his own work.

In the early $18^{\text {th }}$ century, a movement began in Britain, involving the formation of clubs for many purposes not least sports such as cricket, golf, pugilism, and horseracing. They enabled people with a common purpose to come together, provided a basis for agreeing common rules and regulations, created a framework for competitive interaction, and secured a location for participation and sociability. Szymanski has argued that modern British sports emerged from these new forms of associativity, which developed autonomously in Britain following the state retreat from the control of associative activities. This was in contrast, he contends, to the situation in some countries such as France and Germany, where club formation continued to require the explicit or implicit approval of the state.

Herein, modern sports developed in ways consistent with, or even in the service of, the objectives of the state, most notably the need to maintain military preparedness. His critics acknowledge the analysis ambition, but they suggest missing elements and alternative causal factors. They argue that more evidence is required to support the hypothesis; he should have looked further back in time for his European material; he failed adequately to address the issue of class; and he understated the role of commercialisation. More recently, Vamplew has argued for a study of sports clubs using theories of social, cultural, physical, human, and financial capitals. ${ }^{9}$

"Wray Vamplew, "Concepts of capital: an approach shot to the history of the British golf club before 1914", Journal of Sport History, vol. 39, n. 1, 2012. 
Finally, it should be emphasised that, until substantiated by evidence, theories are only competing hypotheses. They might aid our understanding but they do not explain a situation completely. Empirical support is a necessary concomitant for accepting any hypothesis. Moreover, no theory is immutable. If the facts do not fit it, then the historian should check them again and if still convinced they are correct, then the theory should be modified. Historians must not only be prepared to use it, they also must be prepared to adapt it.

\section{Research agenda}

The reader keen to know the state of play in the subject is directed to several recent publications. In a series of 'Presidential Reflections', published in the Journal of Sport History between 2007 and 2009, past presidents of ISHPES, $\mathrm{BSSH}, \mathrm{ASSH}$, and NASSH presented their views on the achievements (and failures) of researchers in their particular domains. Most of the established sports history journals also have issues or detailed articles dealing with the historiography of particular themes. For summaries of the existing knowledge in a variety of countries and areas, readers should consult Pope and Nauright, who provide a comprehensive guide to the international field of sports history since it has been developed as an academic area of study. ${ }^{10}$ A forthcoming publication edited by Edelman and Wilson also analyses the state of current scholarship and summarises ongoing debates, however with a wider thematic approach. ${ }^{11}$

Still much remains to be discovered. Geographically, despite the syntheses by Nauright and Torres respectively, we know little about sport in Africa or in South America. ${ }^{12}$ More work is required on the historical diffusion and cultural transmission of sport between nations. Imperialism has long been a major concern of sports historians, mainly focussing on how Britain exported its sports and games to the colonies and how the recipient countries adopted and adapted them. For those who have the similar knowledge of languages, it is available on French and German the sporting imperialism. Outside formal empire, a project based at the University of Cambridge is examining the spread of sports within Europe focusing on the various responses to the appearance of foreign sports including aversion, resistance, adoption, adaptation, and reinterpretation..$^{13}$ There is also an emerging work on America's sporting empire, not merely the sociological emphasis on globalisation. However, more intracontinental comparisons are needed. The Journal of Sport History, which is the official outlet for NASSH, has yet to publish an article in Mexico, and all comparative work were restricted to the United States and Canada. Also, sports history tend to be conducted within the parameters of the nation state with a reluctance (or an inability) to cross

\footnotetext{
10Steven W. Pope, John Nauright (eds.), Routledge companion to sports history, Abingdon, Routledge, 2010. "Robert Edelman, Wayne Wilson (eds.), Oxford handbook of sport history, Oxford, Oxford University Press, 2013. 12John Nauright, "Africa (sub-Saharan)" In: Steven W. Pope, John Nauright (eds.), Routledge companion to sports history, Abingdon, Routledge, 2010, p. 319-329; and Cesar R. Torres, "South America”, In: Steven W. Pope, John Nauright (eds.), op. cit., p. 553-570.

${ }^{13}$ Alan Tomlinson, Christopher Young, "Towards a new history of European sport", European Review, vol. 17, n. 4, 2011, p. 487-507.
} 
national boundaries. Language can be a barrier but collaborative work can circumvent this as in the previously mentioned project, trying to develop ways of researching an European sports history. Themes such as associativity, gender relations, children in sport and racial/ethnic participation could led themselves to cross-cultural comparisons.

On the economic side, our knowledge is deficient on the production of, and trade in, sporting goods. We know something about the racehorse whose genealogy dates back to the 1600 s, but where did the early sporting equipment come from? The demand for a particular sporting good can be volatile and there is a role here to look at fads and fashion in sporting equipment and apparel. It is also known very little about sports sponsorship and advertising by which business firms tried to make potential customers aware of their products. Historically, it existed with sportsmen endorsing cigarettes and various

Imperialism has long been a major concern
of sports historians, mainly focussing on how
Britain exported its sports and games to the co-
lonies and how the recipient countries adopted
and adapted them

liniments and in brewers painting their names across grandstand roofs, but there have been no studies on either its extent or effectiveness. There is also a great gap in our historical knowledge of sports promoters and entrepreneurs.

Sports history needs its own version of 'history from below', and it should look more at the vast range of informal and unorganised sport practices. Much more is needed on noncompetitive and nonelite sports. Nevertheless, this involves detailed research work with scant academic reward, at short term. To count the number of tennis clubs, defunct and existent, in Nottinghamshire as one amateur enthusiast is undertaking, is a painstaking task and still not that useful without similar work for comparative purposes on either another Nottinghamshire sport or another county's tennis courts. Although there is a plethora of individual club histories, its concept, the voluntary organisation within which most sport takes place, is worthy of further exploration. This ubiquitous institution took many forms including private and work sports clubs, others associated with alcohol trade, religious faiths, politics, education, and military, and stemming from local authority intervention into the recreational sector.

This move away from elite sport could also include that of children, which is relatively untouched. More needs to be done on the role of family but even that other major socialising agency, the school, has not been adequately explored. Within Britain, most work has been directed to the Victorian public schools, though it is still not clear whether the practice matched the rhetoric and how effective the socialisation process was. State schools are practically a virgin territory, though it is from the pupils of such educational institutions that most professional sportspersons emerged. Some children, such as the 
boy jockey and child caddie, were actually employed in a professional sport. Here, there is an opportunity to explore the concepts of child labour (exploitative) versus child work (positive) and the dichotomy between work activities that are social and the instrumental ones.

Two sets of concepts that have been researched extensively but still offer opportunities for further work are race, ethnicity, and gender. Race and ethnicity have featured, particularly in studies from the United States, Australia and South Africa, which have outlined the recognition historical stages in white sporting circles of the black athlete. These have involved novelty value, exclusion, segregation, discrimination and eventually acceptance, though often still carrying stereotyping based on perceptions of black physical ability. Women's position in sports has been extensively covered. For most of the $19^{\text {th }}$ century, and well beyond in many countries, half the population faced restrictions on playing sport simply because they were female. Depending on the sport and nation involved, the mechanisms used included social disapproval from men and women, specialized scientific and medical opinions, and ancillary and regulatory rules imposed by clubs, organisations, and competitions. Yet, little work has been done on other factors such as time demands of employment, child-rearing, and preference for other leisure activities. Nor much has been done on women as spectators despite photographic evidence of their involvement. What is now happening is the acknowledgment that sport and gender are no longer synonymous for sport and women. Masculinities have been added to the gender agenda. Modern sport was established as a male province from its conception and has done much to construct masculinity in many so-

\section{There is a place for the history of the also rans: the marathon runners who hit the wall and the Tour de France cyclists who fail to end a stage}

cieties. As a site of male voluntary activity, sport has been a major method of gender fixing.

One failure by sports historians is to fully grasp the emotion and physicality of sport. It has not been shown how does it feel like to be a passionate football supporter in the 1880s or a bare-knuckled prizefighter before the introduction of gloved boxing. It would be poor history simply to transpose the modern experience of being a fan or participant into the past. Sports historians must search for new source materials in match programmes, local press, diaries, or even novels of that period. Somehow we need to hear those voices.

Another issue that ought to be considered is that to be really representative of sporting participation, sport history must take more cognisance of losers, for losing is the most typical of this type of experiences: there can be only one champion, only one cup-winner. There is a place for the history of the also rans: the marathon runners who hit the wall and the Tour de France cyclists who fail to end a stage. Also, little has been written about those who disliked sport and the reasons for their aversion. 
It should be emphasised that there will never be a final word on any topic researched by sports historians, only the best prevailing opinion at a point in time. As Polley puts it, the past is still being rewritten 'in the light of [...] current needs and interests' as the cultural climate changes new ways of looking at historical issues that are being formulated. ${ }^{14}$ Indeed, Howell has summarised how sports history has changed during his academic career.

[...] the now hackneyed iterations of history from below; the flourishing and withering of social control analysis; the flexible cultural Marxism of the sixties and seventies espoused by Edward Thompson, Raymond Williams, and others; the discipline's fascination with Gramscian notions of hegemony; issues of agency; the emergence of subaltern studies; Foucaultian discourses about social technologies, technique and discipline; the excavation of representations and the imagined worlds of past and present; and the cultural and linguistic turn [...]. All of these have caused changes in the way in which sports historians have gone about their business. ${ }^{15}$

\section{Sports history future}

The sports history world is one of plurality with distinct variations in the origins, development, and current state across the world. This was very clear from the discussion at a forum during the $25^{\text {th }}$ anniversary conference of the British Society of Sports History in 2007, at which the presidents of four major sports history organisations presented their views on the discipline state in their own bailiwicks. A paper by Hoffman and Kay at the NASSH Congress of 2011, which analysed the content of sports history journals and conference programmes in Germany, Britain and the United States, demonstrated the diversity of approach currently on display within these nations. They cautioned that as scholarly work and knowledge exchange become increasingly international, and sport historians regularly present their findings beyond their own national societies, we should be aware that not everybody is singing the same songs at the same time to the same rhythm.

Pope and Nauright stated 'sports history is no longer an academic curiosity', but this does not mean that it has joined the mainstream. ${ }^{16}$ A major problem facing sports historians is that, although some mainstream ones might acknowledge that 'sport is immensely important to any serious attempt to reconstruct a nation's collective life', few read their work. ${ }^{17}$ Whereas sport historians think they have much to offer to debates in globalisation, race and ethnicity, and particularly identity since 'sport helps shaping our sense of who we are', mainstream historians, when they bother at all, see sport history as a source of interesting examples but contributing little to the central issues. ${ }^{18}$ One reason that they may be unaware of good work

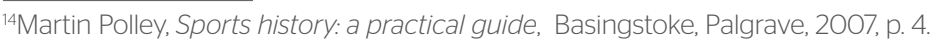

${ }^{15}$ Howell, Colin Howell,"Assessing sport history and the cultural and linguistic turn", Journal of Sport History, vol. 34, n. 3, 2007, p. 460

${ }^{16}$ Steven W. Pope, John Nauright (eds.), Routledge companion to sports history, Abingdon, Routledge, 2010, p. 3.

${ }^{17}$ Martin Johnes, "British sports history: the present and the future", Journal of Sport History, vol. 35, n. 1, 2008 , p. 70.

${ }^{18}$ Jeffrey Hill, Sport in history: an introduction, Basingstoke, Palgrave Macmillan, 2011, p. 73.
} 
is that until recently no sports history journal appeared in the Arts and Humanities or Social Science citation indexes. However, this is starting to change. The International Journal of the History of Sport has just been accepted by Thomson Reuters and the Journal of Sport History by Scopus. Surely, 'Google' may be the salvation of sports history as more articles are scanned into its system. Thus, some mainstream journals have published sports history texts. Among other moves towards closer relations, it is possible to notice that in Australia ASSH has managed to secure a stream within the Australian Historical Association national conference, and the explicit intention of the forthcoming Oxford Handbook of Sport History is to effectively engage with an audience of mainstream historians to whom the work is primarily directed. Hopefully, they can be persuaded that sports history offers a 'dynamic accessible window into politics, economics, gender, race, class formation, ideology, religion, and virtually any discipline.' ${ }^{19}$

Some sports historians believe that to be accepted by the mainstream one has to move down a strongly theoretical avenue. Certainly, this could help establishing a beachhead in progressive mainstream history, especially if theory was modified and developed, not only applied. However, the downside is the possibility that it would drastically curtail nonacademic readerships who have no time for Foucault and Bourdieu's theory or theoretical concepts, such as hegemony and discourse. They would not necessarily accept that historical perspective is a contested terrain with a plurality of meanings and that there are different versions of events depending from whose perspective the narrative is being constructed. Nor might they appreciate Booth's argument that all 'facts are propositional statements about the nature of reality' and that all sources distort or filter the truth and all of them need interpretation. ${ }^{20}$ Such nonacademic amateur sports historians should not be dismissed or abandoned as mere antiquarians. These fans with keyboards may not contextualise well but they usually get their 'sportifacts' right and provide solid bricks with which academic historians can build their arguments. An exemplar here is Vamplew's study about the development of the British golf club using over 300 histories of individual clubs, written mainly by amateur enthusiasts. ${ }^{21}$

Another way forward would lead sports historians to encompass the broader field of leisure history, which might be progressed by connecting with histories of taste, leisure, and consumption. Johnes argues that sport cannot be regarded as special, however it is another kind of leisure. ${ }^{22}$ Sports were physical but dancing and gardening were too. They could be competitive but so could baking and music; they could be social or solitary just like many leisure activities. Johnes adds 'there is surely no emotion or attraction involved in sport that could not also be found in other pastimes. Moreover, the organisations of leisure and sport were based on clubs with rules and regulations. Some academics would even suggest that some

\footnotetext{
19Steven W. Pope (ed.), The new American sport history, Urbana, University of Illinois Press, 1997, p. 3. ${ }^{20}$ Douglas Booth, The field: truth and fiction in sport history, Abingdon, Routledge, 2005, p. 30. ${ }^{21}$ Wray Vamplew, "Concepts of capital: an approach shot to the history of the British golf club before 1914", Journal of Sport History, vol. 39, n. 1, 2012.

${ }_{22}$ Martin Johnes, "British sports history: the present and the future", Journal of Sport History, vol. 35, n. 1, 2008, p. 69.
} 
sports might have more in common with other leisure works than with other sports. Collins has asked what commonality is there between polo at Hurlingham and wrestling in Hull, and suggested that it would 'make more sense to study them in their own particular social contexts, as activities and manifestations of meaning for particular social groups, rather than as part of the continuum of sport.'.

Whatever path is taken, none is likely to dominate the subdiscipline. Currently, there are dichotomies between: who opt for quantification and who prefer a qualitative approach; who seek information at the aggregate level (often the quantifiers) and who look at the individual (mainly the nonstatistical historians); who apply theory and theoretical concepts and who are more empirically focussed; and who pose modern questions in an historical setting and who try to understand what mattered in the past. Different schools of sports history can coexist: they did so in the past, they do so today, so why not in the future? 
